\title{
Development of High-throughput Molecular Markers for Blackleg (Leptosphaeria maculans) Resistance Genes in Brassica napus for Gene Stacking
}

\author{
Zining Wang \\ Department of Plant Science, University of Manitoba, Winnipeg MB R3T 2N2, Canada \\ Current address: Plant Genome Mapping Laboratory, UGA, 111 Riverbend Road, Athens, GA 30602, USA \\ *Corresponding author: wangz@uga.edu
}

Copyright (C 2013 Horizon Research Publishing All rights reserved.

\begin{abstract}
Quinta' and 'Glacier' are two important winter type canola cultivars from Europe. 'Quinta' has two independent blackleg resistance gene loci, $R \operatorname{lm} 1$ and $R \operatorname{lm} 4$; 'Glacier' has two other genes, Rlm2 and Rlm3. This study focuses on mapping the resistance genes Rlm1 and Rlm3 using high throughput SRAP (sequence related amplified polymorphism) markers and SNPs. The $F_{2}$ and $F_{3}$ populations were constructed with crosses of 'Westar' $\times$ 'Quinta' and 'Westar' $\times$ 'Glacier'. The populations were screened with the corresponding isolates. The phenotype segregation in the populations supported that a single dominant resistance gene controls the resistance in 'Quinta' and "Glacier" separately. The closest SRAP marker was identified for the resistance gene in 'Quinta' by using 256 pairs of primers and screening 2,500 polymorphic loci. B342 is $1.5 \mathrm{cM}$ to $R \operatorname{lm} 1$ and $6.8 \mathrm{cM}$ to $R \operatorname{lm} 3$. SNP80870 developed from the N7 orthologous region in Arabidopsis was $3 \mathrm{cM}$ to $R \operatorname{lm} 3$. A population for stacking the three resistance genes (Rlm 1, Rlm3 and LepR3) was constructed. Marker screening and disease inoculation were both used for the selection of lines with the three resistance genes.
\end{abstract}

Keywords Blackleg, Resistance Gene, Marker, Mapping, Gene Stacking, B. Napus

\section{Introduction}

Blackleg, caused by Leptosphaeria maculans, is one of the major diseases in Brassica. In order to understand the Brassica - L. maculans pathosystem, extensive studies have been performed on avirulence genes, resistance genes and their interactions during last two decades. The pathogen was divided into pathogenicity groups (PG), such as PG2, PG3, and PG4 [1,2] via cotyledon inoculation test [3], A1 to A6 $[4,5]$ with the addition of two more differential cultivars and PGT [6]. Blackleg epidemics are caused mostly by PG2 and PG3 worldwide, by PG4 in Europe and by PGT in Canada.
At least sixteen resistance genes to blackleg have been genetically inferred by using the above isolates with the corresponding avirulence genes and were mapped in different sources, such as B. napus, B. rapa, B. juncea and Arabidopsis [6-17]. The resistance gene LepR3 was recently cloned [18].

At least five resistance genes were mapped on linkage group N7 via genetic studies of segregating populations. Rlmland Rlm3 controlling seedling resistance to PG3 and PG2 were mapped on the DY10 linkage groups $[8,12,19,20,21]$ that was later confirmed an equivalence to N7 [7,15,21,22]. Rlm3 in 'Glacier', 'Columbus' and 'Maxol' [23] was linked to the field resistance $R \operatorname{lm} 1$ as a QTL locus with a genetic distance of $26 \mathrm{cM}$. Rlm4 in 'Quinta' was linked to $R \operatorname{lm} 1$ [12] with a genetic distance of $19 \mathrm{cM}$. Rlm2 in 'Glacier' and 'Samourai', controlling seedling resistance to PG2 isolates in these cultivars, was on linkage group LG16 [12]. At least five resistance genes $(R \operatorname{lm} 1, R \operatorname{lm} 3, R \operatorname{lm} 4, R \operatorname{lm} 7$ and $R \operatorname{lm} 9$ ) in a cluster were located in this region [12]. $L m R 1$ in 'Sheralee', CLmR1 in 'Cresor', CRLMm in 'Maluka', $C R L M r b$ in RB87-62, and $c R L M j$ in DH88-752 were all mapped on LG6 that also belongs to linkage group N7 [6, 21]. As quite a few genes were mapped on N7, development of closely linked markers in this hotspot region is necessary for gene identification and marker assisted selection.

Marker assisted gene stacking is intended to integrate specific genes and/or QTLs for the trait(s) into a single genotype [24] with the advantage of increasing selection efficiency for multiple genes [25-27]. There are quite a few successful examples for gene stacking of more than two traits or pathogens [28,29], stacking specific resistance with quantitative resistance QTLs [30] and stacking only specific resistance genes to the same pathogen [31]. Factors, such as marker distance, generations, population size and heritability [32-42] are the main elements to be considered when using marker assisted selection. However, the closeness of the molecular markers used for the selection is the key for success $[25,34,38,40,43,44]$.

In this study, we screened the SRAP markers using the 
primer combinations and developed SNPs in the N7 region using the populations constructed with 'Westar', 'Quinta' and 'Glacier' respectively. Closely linked markers were identified for two blackleg resistance genes. The gene stacking population was also constructed to produce lines with multiple resistance genes. Disease inoculation and marker screening were combined for the selection of the stacked resistance genes.

\section{Materials and Methods}

\subsection{Construction of Populations}

The plants of B. napus cultivars 'Westar', 'Glacier', 'Quinta', 'Surpass 400' and 'Cresor' were grown in a temperature and light controlled growth chamber with 16 hours of light at $21^{\circ} \mathrm{C}$, followed by 8 hours of darkness at $19^{\circ} \mathrm{C}$. The $\mathrm{F}_{1}$ seeds from the mapping populations, such as 'Westar' $\times$ 'Glacier' and 'Westar' $\times$ 'Quinta', were obtained by pollinating 'Westar' flower stigmas with 'Glacier' and 'Quinta' pollen, respectively. The $F_{2}$ seeds were obtained by selfing the $F_{1}$ plants in selfing bags. The $F_{2}$ plants were bagged to produce $F_{3}$ seeds. The $F_{3}$ plants selfed to produce $F_{4}$ seeds for later use. For the gene stacking population, four-way crossing was adopted as 'Crèsor' × 'Quinta'//'Surpass 400' × 'Glacier'. The resulting population was screened by both the disease inoculation and the selected markers.
The $F_{2}$ and $F_{3}$ plants were inoculated separately with blackleg pycnidiospore suspension of $2 \times 10^{7}$ spores $/ \mathrm{ml}$ at the cotyledon stage in order to phenotype the segregating populations. The cotyledons were punctured with forceps. Ten $\mu 1$ of the suspension was dropped on each puncture. The plants were kept at room temperature with light overnight for recovery. Then the plants were grown in the controlled growth chamber. In 12 days, the disease symptoms were fully developed, and the disease severity was rated according to the classification of 0 to 9 [45]. Disease severity 0 to 6 was classified as resistant and 7 to 9 as susceptible. Each time, the parental lines and their $F_{1}$ were used as controls. Two to 3 time replications in $\mathrm{F}_{3}$ were needed in the case of unstable symptoms. In this study,

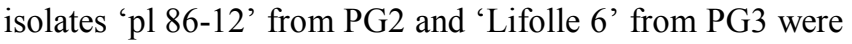
used for the populations 'Westar' $\times$ 'Glacier' and 'Westar' $\times$ 'Quinta', respectively. '87-41" was used for the phenotyping of resistance gene LepR3 from 'Surpass 400' [15].

\subsection{Genotyping of the Populations}

A modified $\mathrm{CTAB}$ extraction procedure described in $\mathrm{Li}$ and Quiros [46] was used for DNA extraction. Sequence related amplified polymorphism (SRAP) was applied in the PCR reactions with 5 cycles at $94^{\circ} \mathrm{C} 50 \mathrm{~s}, 35^{\circ} \mathrm{C} 50 \mathrm{~s}$ and $72^{\circ} \mathrm{C} 50 \mathrm{~s}$, followed by 30 cycles at $94^{\circ} \mathrm{C} 50 \mathrm{~s}, 50^{\circ} \mathrm{C} 50 \mathrm{~s}$ and $72^{\circ} \mathrm{C} 50 \mathrm{~s}$. The markers were detected using ABI 3100 Genetic Analyzer (Life Technologies, New York, USA) according to the user manual.

\subsection{Phenotyping of the Populations}

Table1. Primers designed for SNP development between 'Westar', 'Quinta' and 'Glacier'

\begin{tabular}{|c|c|c|c|}
\hline Name & Primer Sequence & Genes* & Amplicon (bp) \\
\hline WB26 & GAACCATCCCTTTCGACGTT & At1g80870 & 1,300 \\
\hline WB27 & AGCTAAATTCTCCCGCTGCT & & \\
\hline WB18 & TGCTTGGAAAGATGATGGAAC & At1g80670 & 1,100 \\
\hline WB19 & CGGGTGGAAATTCAGAGAGT & & \\
\hline WB20 & AGGTTTGGGAGATCCCGTAG & At1g80680 & 1,400 \\
\hline WB21 & TGAACTGTCGGGAGGTAGATG & & \\
\hline WB22 & GCGTTCGCTCTACTTTCGTC & Atlg80630 & 1,150 \\
\hline WB23 & TTATGCCCGTACATCTGCTG & & \\
\hline WB24 & TCCGTTGTCTACGTTTCTGG & At1g80640 & 1,000 \\
\hline WB25 & CCAAAGATCCATTCTGCATCA & & \\
\hline WB28 & CCAATTGGACCAGAGCATTA & At1g79640 & 1,100 \\
\hline WB29 & TGAGCAAGCTCTAGCCCAGT & & \\
\hline WB30 & TCCCTTTTTCATCACCGACT & At1g79670 & 1,300 \\
\hline WB31 & CGAGACAACACCCCATGAGT & & \\
\hline WB32 & AGAATCCAAGGGATGCAAAG & At1g79680 & 1,200 \\
\hline WB33 & CAGCAATACGAAGACGCACT & & \\
\hline WB34 & GCTCTGCGTTCTTTGATGG & At1g79620 & 850 \\
\hline WB35 & TGTCAACTGATTATCCGCAAG & & \\
\hline WE15 & GAAGAACTTGCAGAGCTTCAG & At1g79600 & 960 \\
\hline WE16 & CTTCAGAGCATAGTAATCTCG & & \\
\hline
\end{tabular}

* Primer sequences are from 5' - 3'. At1g79600 to At1g80870 are Arabidopsis genes. 
For the SNP development, ten genes (Table 1) from a N7-orthologous-region on Arabidopsis chromosome 1 were selected for primer design [47]. The specific PCR was performed at $94^{\circ} \mathrm{C} 50 \mathrm{~s}, 50-60^{\circ} \mathrm{C} 50 \mathrm{~s}$ and $72^{\circ} \mathrm{C} 50 \mathrm{~s}$ for 35 cycles. The quality of the amplicons was visualized in the agarose gel with the BIO-RAD Gel Doc 2000. The PCR products were diluted 3 to 5 times and $2 \mu \mathrm{l}$ was used as the sequencing template. The PCR reactions were performed at $94^{\circ} \mathrm{C} 4 \mathrm{~min}$, then at $94^{\circ} \mathrm{C} 30 \mathrm{~s}, 50^{\circ} \mathrm{C} 10 \mathrm{~s}$ and $60^{\circ} \mathrm{C} 4 \mathrm{~min}$ for 25 to 30 cycles. The SNPs were identified by comparing the sequences of 'Westar', 'Glacier' and 'Quinta' using the SeqA software installed on ABI 3100 Genetic Analyzer according to the settings. The SNPs were then used to screen the segregating populations. Both the SNP and the SRAP markers were used for linkage analysis.

(V2.0) was used to generate the linkage map with LOD 4.0 .

\subsection{Disease Resistance Mapping}

The DNA samples from 8 resistant plants and 8 susceptible plants were used to run SRAP markers first. Once a few close markers were identified, the sample number was increased to 32 to 32 , or all the samples were used for marker screening. Only the closely linked markers were used to construct the genetic map. Mapmaker

\section{Results}

\subsection{Segregation of Resistance in the Populations}

For the populations of 'Westar' $\times$ 'Glacier', screened by the PG2 isolate 'pl 86-12', the parent 'Westar' was completely susceptible, $F_{1}$ and the other parent 'Glacier', resistant and the plants in the populations segregated in resistance phenotype. Segregation in the $F_{2}$ generation showed a 3:1 ratio of resistant and susceptible plants. The $F_{3}$ generation showed a 1:1:1 ratio of resistant, segregating and susceptible plants (Table 2). Most $F_{3}$ plants showed corresponding phenotypes to their $\mathrm{F}_{2}$ plants. Segregation of both the populations suggested a specific dominant resistance gene model.

For the population 'Westar' $\times$ 'Quinta', screened by the PG3 isolate 'Lifolle 6', the parent 'Westar' showed complete susceptibility, $F_{1}$, intermediate resistance and the other parent 'Quinta', resistance. The plants in the populations segregated in resistance phenotype. Segregation in $F_{2}$ showed a ratio of 3 resistant to 1 susceptible and a 1:2:1 ratio for the number of resistant, segregating and susceptible plants in $F_{3}$ (Table 2). The phenotypes of most $F_{3}$ plants showed agreement to the corresponding $F_{2}$ plants. Segregation of both the populations suggested a specific dominant resistance gene model.

\subsection{Screening of SRAP Markers}

Screening of SRAP molecular markers were started by running 'Westar' $\times$ 'Quinta' population with 8 susceptible plants to 8 resistant plants from $F_{2}$. Two hundred and fifty-six primer pairs [48] were used for the initial screening. About 2,500 markers were polymorphic. One of the markers, B342, was found to co-segregate with the resistance gene in 'Quinta'. Forty-eight plants from the populations were used to test this marker. This marker was still closely linked to the plant resistance. After searching the consensus linkage mapping group $\mathrm{N} 7$, this marker could not be found on the map [48]. The marker B342 was used to screen the whole population. After all the $F_{2}$ plants were screened with this marker, it showed a genetic distance of $1.5 \mathrm{cM}$ to the resistance gene (Fig.1).

For the 'Glacier' resistance gene, the marker, B342, was used to screen the $F_{2}$ and $F_{3}$ generations of 'Westar' $\times$ 'Glacier'. The marker is $6.8 \mathrm{cM}$ away from the resistance gene in 'Glacier' (Fig. 1).

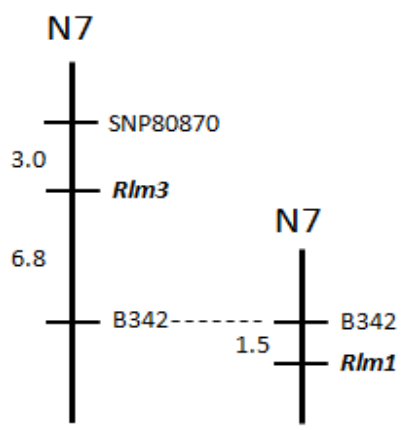

Figure 1. Localization of $R \operatorname{lm} 1$ linkage group from 'Westar' $\times$ 'Quinta' and $R \operatorname{lm} 3$ linkage group from 'Westar' $\times$ 'Glacier'. Blackleg resistance genes Rlm 1 from 'Quinta' and Rlm3 from 'Glacier' were both mapped on the N7 linkage group. Numbers at left side show the genetic distance between the markers and the genes in centiMorgans.

Table 2. Segregation of resistance in the population*

\begin{tabular}{ccccccccc}
\hline Population & Generation & \multirow{2}{*}{ Ratio } & \multicolumn{3}{c}{ No. of Plants } & \multirow{2}{*}{$\mathrm{X}^{2}$} & $\mathrm{P}$ \\
\cline { 4 - 6 } & & & $\mathrm{R}$ & $\mathrm{Se}$ & $\mathrm{S}$ & & $<0.05$ \\
\hline 'Westar'×'Glacier' & $\mathrm{F}_{2}$ & $3: 1$ & 117 & & 37 & 0.1168 & 3.841 \\
& $\mathrm{~F}_{3}$ & $1: 2: 1$ & 30 & 67 & 35 & 0.4242 & 3.841 \\
'Westar'×'Quinta' & $\mathrm{F}_{2}$ & $3: 1$ & 238 & & 70 & 0.8485 & 3.841 \\
& $\mathrm{~F}_{3}$ & $1: 2: 1$ & 48 & 104 & 57 & 0.7798 & 3.841 \\
\hline
\end{tabular}

*For 'Westar' $\times$ 'Glacier', cotyledon inoculations were conducted with the pycnidiospore suspension of isolate pl 86-12 at $2 \times 10^{7}$. 'Westar' $\times$ 'Quinta' progenies were inoculated with isolate Lifolle 6 . The disease ratings followed the $0-9$ scales. Ratings $0-6$ were resistance and 7-9 were susceptible. Each $\mathrm{F}_{3}$ family had 12 plants inoculated. The heterozygous family in $\mathrm{F}_{3}$ were determined if there was phenotypic segregation 


\subsection{Development of SNPs Markers}

Of the ten primer pairs designed from Atlg79600 to Atlg80870 for the detection of SNPs in N7, one SNP ('Westar': CTTTCT; 'Quinta' and 'Glacier': CCTTTT) was found in At1g80870 by comparing the sequences of 'Westar', 'Glacier' and 'Quinta'. SNP80870 was used to screen the two populations, 'Westar' $\times$ 'Glacier' and 'Westar' $\times$ 'Quinta'. It showed a linkage to the resistance gene $R \operatorname{lm} 3$ in 'Glacier' with a genetic distance of $3.0 \mathrm{cM}$ (Fig. 1). However, SNP80870 did not show any linkage to Rlm1 in 'Quinta'.

\subsection{Comparative Mapping of Resistance Genes from 'Quinta' and 'Glacier'}

As the two genetic maps had a consensus marker B342, $R \operatorname{lm} 1$ and $R \operatorname{lm} 3$ both were mapped in the N7 linkage group and had a genetic distance of $11.3 \mathrm{cM}$. Marker SNP80870 was closely associated with $R \operatorname{lm} 3$ from 'Glacier'. B342 was more closely linked to $R \operatorname{lm} 1$ with a distance of $1.5 \mathrm{cM}$, while it was loosely linked to the gene $R \operatorname{lm} 3$ in a distance of $6.8 \mathrm{cM}$ (Fig. 1).

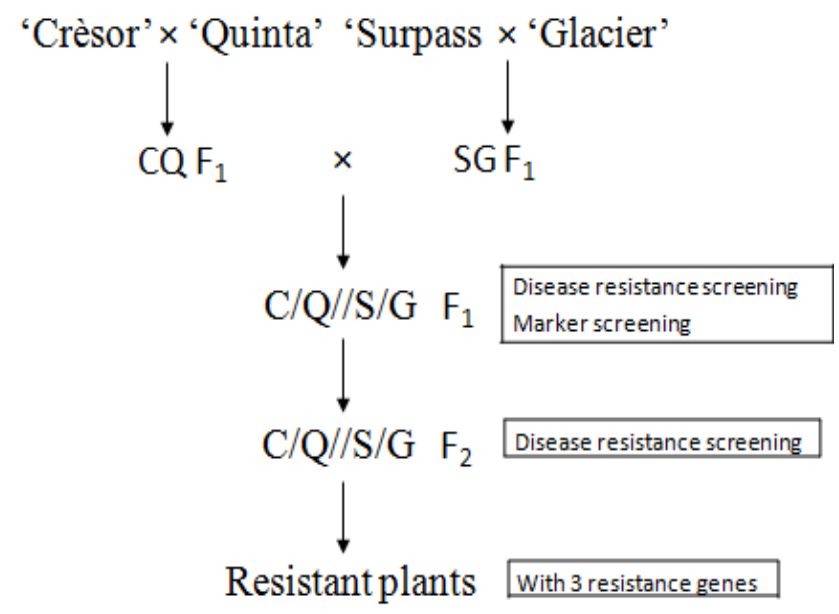

Figure 2. Blackleg resistance gene stacking procedure. ' $\mathrm{C} / \mathrm{Q} / / \mathrm{S} / \mathrm{G}$ ' refers to 'Crèsor/Quinta//Surpass400/Glacier'.

\subsection{Blackleg Resistance Gene Stacking}

Figure 2 shows the gene stacking procedure. The population was constructed with four cultivars, 'Cresor', 'Quinta', 'Surpass 400' and 'Glacier'. For the first round crossing, parental lines of both spring and winter type were used in order to reduce the time for vernalization for the $F_{1}$ and select the spring type of plants in later generations. The $\mathrm{F}_{1} \mathrm{~S}$ of the two combinations were then crossed to obtain the $\mathrm{F}_{1}(\mathrm{C} / \mathrm{Q} / / \mathrm{S} / \mathrm{G})$ of the four way crossing. The $\mathrm{F}_{1}(\mathrm{C} / \mathrm{Q} / / \mathrm{S} / \mathrm{G})$ was not treated in the cold room and was segregating in disease resistance and flower time. We inoculated their

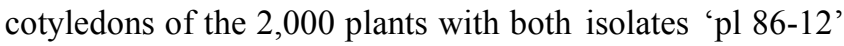
and 'Lifolle 6' each on one cotyledon. We selected only 45 plants showing resistance to both isolates, discarding the winter type plants and the other plants. After screening with B342, SNP80870 and 0127Fr382 the closest marker $(0.3$ $\mathrm{cM}$, unpublished) to LepR3, 12 plants were confirmed to have the three resistance genes and were used for next generation. In the $\mathrm{CQSG} \mathrm{F}_{2}$ generation, 6 plants from each of the 12 families were inoculated with 87-41 and were confirmed the existence of LepR3 in these plants. Considering the agronomic traits when harvesting these plants, we selected only three lines as the best resistance candidates for the use in breeding.

\section{Discussion}

In this study, we confirmed the genetic model of Rlm 1 from 'Quinta' and $R \operatorname{lm} 3$ from 'Glacier' respectively. Through the mapping of each gene, we identified very closely linked markers that can be used for automated screening of the breeding populations. The comparative mapping of the two genes indicates the $\mathrm{N} 7$ region containing at least 5 resistance genes would be a hotspot region for elucidating genetic control and evolution of these genes. The successful selection of lines with multiple blackleg resistance genes will broaden the genetic basis for development of resistant cultivars.

'Quinta' and 'Glacier' are winter type European cultivars with blackleg resistance $[19,49]$. Segregation data from both studies indicated that one dominant resistance gene controlled blackleg resistance in each cultivar. In this study, as we used the same isolate and populations as used by Keri [49], the results were consistent with the previous studies. $R \operatorname{lm} 1$ in 'Quinta' and $R \operatorname{lm} 3$ in 'Glacier' were previously mapped on the linkage group DY10 [12] that was determined to be the same as N7 [16]. The closest markers to gene $R \operatorname{lm} 1$ and $R \operatorname{lm} 3$ are at least $7 \mathrm{cM}$ away, indicating the use of these markers in marker assisted selection should be very difficult. In this study, we screened 2,500 SRAP markers and the marker B342 was only $1.5 \mathrm{cM}$ to $R \operatorname{lm} 1$. Further, we developed some SNP markers and SNP80870 is $3 \mathrm{cM}$ to Rlm1. These closer markers had been used in the marker assisted selection for blackleg resistance.

In the genetic maps, $R \operatorname{lm} 1, R \operatorname{lm} 3, R \operatorname{lm} 4, R \operatorname{lm} 7$ and $R \operatorname{lm} 9$ were located in a $40 \mathrm{cM}$ interval on linkage group DY10 [12]. Colinear markers indicated that these genes were in a gene cluster. $R \operatorname{lm} 1$ and $R \operatorname{lm} 3$ covered an interval of $34 \mathrm{cM}$. In this study, the two genes were linked by a consensus marker B342 that was linked to a marker SNP80870 developed from N7, confirming the existence of the genes on N7. Rlm 1 and $R \operatorname{lm} 3$ on $\mathrm{N} 7$ cover a region of $11.3 \mathrm{cM}$ that is different from the interval of $34 \mathrm{cM}$ on DY10. The difference in one parental line for the populations could be the major cause for the genetic difference. Similar results were also obtained for LmR1 in 'Shiralee' and CLmR1 in 'Cresor' [21].

Nine resistance genes to blackleg have been mapped on the N7 linkage group. $R \operatorname{lm} 1, R \operatorname{lm} 3, R \operatorname{lm} 4, R \operatorname{lm} 7$, and $R \operatorname{lm} 9$ 
were defined with the avirulence genes confirmed by tetrad studies [12]. Other genes such as LmR1,CLmRm, CRLMrb and $c R L M j$ correspond to unknown avirulence genes. Difference in genetic background will delay the elucidation of the gene cluster. Comparative fine mapping and physical mapping will help reveal how many different resistance genes are located in this region. In this study, SNP80870 was developed from the flanking regions of $L m R 1$ and $C L m R 1$. As SNP80870 was linked closely to $R \operatorname{lm} 3$, there is a possibility that $L m R 1$ and $C L m R 1$ are Rlm3. However, genotyping by sequencing seems to be the most effective method to tackle the genes in this region.

Marker assisted gene stacking has the advantage of increasing the efficiency for variety development $[25,26]$ in targeting multiple genes simultaneously [27] that could not easily followed by traditional breeding methods. In this study, we identified two markers for two blackleg resistance genes via high throughput SRAP and SNP development. The combination of marker screening with disease inoculation made the selection of target genotypes more efficient. However, both the inoculation of plants in each generation and the extraction of a large number of DNA samples for marker screening are tedious jobs even with a robot system. We combined the cotyledon inoculation with marker screening at the same generation. This saved time and costs normally spent in the later generations.

Closely linked markers can increase the efficiency for disease resistance selection from decreased population sizes. The flanking markers of a major gene can increase the selection efficiency [43]. In this study, B342, as the flanking marker of only $1.5 \mathrm{cM}$ for the major resistance gene locus $R \operatorname{lm} 1$ in 'Quinta', can be used as a major marker for $R \operatorname{lm} 1$ gene selection in a smaller population than the traditional breeding populations. The marker SNP80870 is $3.0 \mathrm{cM}$ to $R \operatorname{lm} 3$ and can be used either alone or combined with B342 to track $R \operatorname{lm} 3$. The population size can be decreased when the two flanking markers for each gene are used for the selection. As a consensus marker of $R \operatorname{lm} 1$ and $R \operatorname{lm} 3, \mathrm{~B} 342$ can target both genes in one population. These molecular markers could be very useful for stacking blackleg resistance gene.

Race-specific resistance genes in breeding are facing potential risks [50-53] and could be easily overcome by a mutation in the pathogen [54]. The three major resistance genes derived from B. rapa $\mathrm{ssp}$. sylvestris and B. juncea were overcome by L. maculans in France and Australia [55-57]. In addition to finding new effective resistance genes, QTLs stacking is expected to be more effective than stacking a few single genes because they are controlled by multiple genes that could not be overcome by the pathogens simultaneously. Horizontal resistance could be the breeding objective of breeders.

\section{REFERENCES}

[1] A. Mengistu, S. R. Rimmer, P. H. Williams, 1991
Pathogenicity grouping of isolates of Leptosphaeria maculans on Brassica napus cultivars and their disease reaction profiles on rapid-cycling Brassicas. Plant Dis $75: 1279-1282$

[2] E. Koch, K. Song, T. C. Osborn, P. H. Williams, 1991 Relationship between pathogenicity and phylogeny based on restriction fragment length polymorphisms in Leptosphaeria maculans. Mol Plant-Microbe Interact 4:341-349

[3] P. H. Williams and P. A. Delwiche. Screening for resistance to blackleg of Crucifers in the seedling stage. Proc. Eucarpia Conf. Breed. Cruciferous Crops, Wageningen, Pays-Bas, the Netherlands, 164-170, 1979

[4] H. M. A. Badawy, H. H. Hoppe, E. Koch, 1991 Differential reactions between the genus Brassica and aggressive single spore isolates of L. maculans. J. Phytopathology 15:109-119

[5] M. H. Balesdent, A. Attard, D. Ansan-Melayah, R. Delourme, M. Renard, T. Rouxel, 2001 Genetic control and host range of avirulence toward Brassica napus cultivars "Quinta" and "Jet Neuf" in Leptosphaeria maculans. Phytopathology 91:70-76

[6] S. R. Rimmer, 2006 Resistance genes to Leptosphaeria maculance in Brassica napus. Can. J. Plant Pathol. 28:288-297

[7] M. E. Ferreira, S. R. Rimmer, P. H. Williams, T. C. Osborn, 1995 Mapping loci controlling Brassica napus resistance to Leptosphaeria maculans under different screening conditions. Phytopathology 85:213-217

[8] R. Mayerhofer, V. K. Bansal, M. R. Thiagarajah, G. R. Stringam, A G. Good, 1997 Molecular mapping of resistance to Leptosphaeria maculans in Australian cultivars of Brassica napus. Genome 40:294-301

[9] M. L. Pilet, R. Delourme, N. Foisset, M. Renard, 1998 Identification of loci contributing to quantitative field resistance to blackleg disease, causal agent Leptosphaeria maculons (Desm.) Ces. et de Not., in winter rapeseed (Brassica napus L.). Theor. Appl. Genet. 96:23-30

[10] S. R. Rimmer, M. H. Borhan, B. Zhu, D. Somers. Mapping resistance genes in Brassica napus to Leptosphaeria maculans. "New Horizons for an old crop." In: Proceedings of the 10th international rapeseed congress, Canbera, Australia, 1999

[11] B. Zhu, R. Rimmer, 2003 Inheritance of resistance to L. maculans in two accessions of $\mathrm{B}$. napus. The Canadian Journal of Plant Pathology 3:98-103

[12] R. Delourme, M. L. Pilet-Nayel, M. Archipiano, R. Horvais, X. Tanguy, T. Rouxel, H. Brun, M. Renard, M. H. Balesdent, 2004 A cluster of major specific resistance genes to Leptosphaeria maculans in Brassica napus. Phytopathology 94:578-583

[13] R. Delourme, A. M. Chèvre, H. Brun, T. Rouxel, M. H. Balesdent, J. S. Dias, P. Salisbury, M. Renard, S. R. Rimmer, 2006 Major Gene and Polygenic Resistance to Leptosphaeria maculans in Oilseed Rape (Brassica napus). European Journal of Plant Pathology 114(1): 45-52

[14] J. Staal, M. Kaliff, S. Bohman, C Dixelius, 2006 Transgressive segregation reveals two Arabidopsis TIR-NB-LRR resistance genes effective against Leptosphaeria maculans, causal agent of blackleg disease. 
Plant J. 46(2):218-30

[15] Y Long, Z. Wang, Z. Sun, D. W. Fernando, P. B. E. McVetty, G. Li, 2011 Identification of two blackleg resistance genes and fine mapping of one of these two genes in a Brassica napus canola cultivar 'Surpass 400'. Theor. Appl. Genet. 122:1223-1231

[16] F. Yu, D. J. Lydiate, S. R. Rimmer, 2005 Identification of two novel genes for black leg resistance in Brassica napus. Theor. Appl. Genet. 110(5):969-979

[17] F. Yu, R. K, Gugel, H. R. Kutcher, G. Peng, S. R. Rimmer, 2013 Identification and mapping of a novel blackleg resistance locus LepR4 in the progenies from Brassica napus x B. rapa subsp. sylvestris. Theor. Appl. Genet. 126:307-315

[18] N. J. Larkan, D. J. Lydiate, I. A. Parkin, M. N. Nelson, D. J. Epp, W. A. Cowling, S. R. Rimmer, M. H. Borhan, 2013 The Brassica napus blackleg resistance gene LepR3 encodes a receptor-like protein triggered by the Leptosphaeria maculans effector AVRLM1. The New phytologist 197:595-605

[19] D. Ansan-Melayah, M. H. Balesdent, M. Buée, T. Rouxel, 1995 Genetic characterization of avrLm1, the first avirulence gene of Leptosphaeria maculans. Phytopathology $85: 1525-1529$

[20] D. Ansan-Melayah, M. H. Balesdent, R. Delourme, M. L. Pilet, X. Tanguy, M. Renard, T. Rouxel, 1998 Genes for race-specific resistance against blackleg disease in Brassica napus L. Plant Breed 117:373-378

[21] R. Mayerhofer, K. Wilde, M. Mayerhofer, D. Lydiate, V. K. Bansal, A. G. Good, I. A. P. Parkin, 2005 Complexities of chromosome landing in a highly duplicated genome: Toward map-based cloning of a gene controlling blackleg resistance in Brassica napus. Genetics 171:1977-1988

[22] I. A. P. Parkin, A. G. Sharpe, D. J. Keith, D. J. Lydiate, 1995 Identification of the $\mathrm{A}$ and $\mathrm{C}$ genomes of amphidiploid Brassica napus (oilseed rape). Genome 38:1122-1133

[23] M. H. Balesdent, A. Attard, M. L. Kuhn, T. Rouxel, 2002 New avirulence genes in the phytopathogenic fungus Leptosphaeria maculans. Phytopathology 92:1122-1133

[24] D. P. Johan, J. R. van der Voort, 2003 The challenges in Marker Assisted Breeding. Eucarpia Leafy Vegetables: $125-130$

[25] J. W. Dudley, 1993 Molecular markers in plant improvement: manipulation of genes affecting quantitative traits. Crop Sci. $33: 660-668$

[26] M. Lee, 1995. DNA markers in plant breeding programs. Adv. Agron. 55:265-344

[27] S. Singh, J. S. Siduhu, N. Huang, Y. Vikal, Z. Li, D. S. Brar, H. S. Dhaliwal, G. S. Khush, 2001 Pyramiding three bacterial blight resistance genes (xa5, xa13 and Xa21) using marker-assisted selection into indica rice cultivar 'PR106'. Theor. Appl. Genet. 102:1011-1015

[28] Y. Q. He, X. Li, I. F. Zhang, G. H. Jiang, S. P. Liu, S. Chen, J. Mm Tu, C. G. Xu, Q. F. Zhang, 2004 Gene pyramiding to improve hybrid rice by molecular marker techniques. Poster at http://www.cropscience.org.au/

[29] K. Datta, N. Baisakh, K. M. Thet, J. Tu, S. K. Datta, 2002
Pyramiding transgenes for multiple resistances in rice against bacterial blight, yellow stem borer and sheath blight. Theor Appl Genet 106(1):1-8

[30] M. Ashikari, M. Matsuoka, 2006 Identification, isolation and pyramiding of quantitative trait loci for rice breeding. Trends Plant Sci. 11(7):344-50

[31] P. N. Sharma, A. Torii, S. kumi, N. Mori, C. Nakamura, 2004 Marker-assisted pyramiding of brown planthopper (Nilaparvata lugens Stal) resistance genes Bph1 and Bph2 on rice chromosome 12. Hereditas 140(1):61-9

[32] W. Zhang, C. Smith, 1992 Computer simulation of marker-assisted selection utilizing linkage disequilibrium. Theor. Appl. Genet. 83:813-820

[33] W. Zhang, C. Smith, 1993 Simulation of marker-assisted selection utilizing linkage disequilibrium: the effect of several additional factors. Theor. Appl. Genet. 86:492-496

[34] M. D. Edwards, N. J. Page, 1994 Evaluation of marker-assisted selection through computer simulation. Theor. Appl. Genet. 88:376-382

[35] A. Gimelfarb, R. Lande, 1994a Simulation of marker-assisted selection in hybrid populations. Genet. Res. 63:39-47

[36] A. Gimelfarb, R. Lande, 1994b Simulation of marker-assisted selection for non-additive traits. Genet. Res 64:127-136

[37] A. Gimelfarb, R. Lande, 1995 Marker-assisted selection and marker-QTL associations in hybrid populations. Theor. Appl. Genet. 91:522-528

[38] F. Hospital, L. Moreau, F. Lacoudre, A. Charcosset, A. Gallais, 1997 More on the efficiency of marker-assisted selection. Theor. Appl. Genet. 95:1181-1189

[39] J. C. Whittaker, C. S. Haley, R. Thompson, 1997 Optimal weighting of information in marker-assisted selection. Genet. Res. 69:137-144

[40] L. Moreau, A. Charcosset, F. Hospital, A. Gallais, 1998 Marker-assisted selection efficiency in populations of finite size. Genetics 148:1353-1365

[41] Z. W. Liu, T. D. Fu, X. P. Liu, J. X. Tu, B. Y. Chen, 2005 The research status, factors and strategy for marker assisted selection. Chinese Bulletin of Botany 22(Supplement): 82-90

[42] X. Li, 2006 Issues and strategy for marker assisted selection. icgr.caas.net.cn/973/MAS.html

[43] S. D. Tanksley, 1983 Molecular markers in plant breeding. Plant Mol. Biol. Rep. 1:3-8

[44] R. Spelman, H. Bovenhuis, 1998 Genetic response from marker assisted selection in an outbred populaton for differing marker bracket sizes and with two identified quantitative trait loci. Genetics 148:1389-1396

[45] P. H. Williams, C. B. Hill. Crucifer Genetics Cooperative: Resource Book. Madison: Crucifer Genetics Cooperative, 1985

[46] G. Li, C. F. Quiros, 2001 Sequece-related amplified polymorphism (SRAP), a new marker system based on a simple PCR reaction: its application to mapping \& gene tagging in Brassica. TAG 103:455-461 
[47] I. A. P. Parkin, S. M. Gulden, A. G. Sharp, L. Lukens, M. Trick, T. C. Osborn, D. J. Lydiate, 2005 Segmental structure of the Brassica napus genome based on comparative analysis with Arabidopsis thaliana. Genetics 171:765-781

[48] Z. D. Sun, Z. N. Wang, J. X. Tu, J. F. Zhang, G. Y. Li , P. B. E. McVetty, 2007 An ultradense genetic recombination map for Brassica napus, consisting of 13,551 SRAP markers. TAG 114:1305-17

[49] M. Keri. Genetic studies of host - pathogen interaction between Brassica napus and Leptospheria maculans. Ph.D thesis. Department of Science, University of Manitoba, 1999

[50] J. E. van der Plank. Plant diseases: epidemics and control. Academic Press, New York, 1963

[51] J. E. van der Plank. Ganetic and molecular basis of pathogenesis. Springer Verlag. Berlin 166, 1978

[52] R Johnson, 1984 A critical analysis of durable resistance. Annu. Rev. Phytopathol 22: 309-330

[53] J. E. Parleviet, H. J. Kuiper, 1977 Resistance of some barley cultivars to leaf rust, Puccinia hordei: Polygenic partial resistance hidden by monogenic hypersensitivity. Neth. J. Plant Pathol 83:85-889

[54] J. E. Parlevliet, 1983 Race-specific resistance and cultivar-specific virulence in the barley-leaf rust pathosystem and their consequences for the breeding of leaf rust resistant barley. Euphytica 32:367-375

[55] C. X. Li, W. A. Cowling, 2003 Identification of a single dominant allele for resistance to blackleg in Brassica napus 'Surpass 400'. Plant Breeding 122 (6):485-489

[56] T. Rouxel, A. Penaud, X Pinochet, H. Brun, L. Gout, R. Delourme, J. Schmidt, M. H. Balesdent, 2003 A ten-year survey of populations of Leptosphaeria maculans in France indicates a rapid adaptation towards the Rlm1 resistance gene of oilseed rape. Eur. J. Plant Pathol 109:871-881

[57] S. J. Sprague, M. H. Balesdent, H. Brun, H. L. Hayden, S. J. Marcroft, X. Pinochet, T. Rouxel, B. J. Howlett, 2006 Major gene resistance in Brassica napus (oilseed rape) is overcome by changes in virulence of populations of Leptosphaeria maculans in France and Australia. European Journal of Plant Pathology 114:33-40 